\title{
Business Intelligence Implementation Success Framework: A Literature Review
}

\author{
Haitham Alali* \\ Business Faculty, Amman Arab University, PO box 2234, Amman 11953, Jordan \\ MI Nofal \\ Business Faculty, Amman Arab University, PO box 2234, Amman 11953, Jordan \\ Malek Alharafsheh \\ Business Faculty, Amman Arab University, PO box 2234, Amman 11953, Jordan
}

\begin{abstract}
In contemporary competitive business context, managers are increasingly using Business Intelligence (BI) as the technique and solution to improve their understanding of a business environment. This paper introduces studies performed on the implementation of BI in SMEs between 2000 and 2015, and it is multi-purpose. First, it examines types of research questions addressed by studies of BI carried out in developing countries. Second, its purpose is to identify the gaps in the BI studies in these countries. Third, it aims to be a base for developing a framework for BI implementation success through the classification of the critical success factors (CSFs) found in the relevant literature. Due to this model, BI stakeholders can identify and understand the crucial factors behind the successful implementation of BI systems in SMEs.
\end{abstract}

Keywords: business intelligence, small and medium-sized enterprises, literature review, critical success factors. DOI: $10.7176 /$ EJBM/11-6-02

\section{INTRODUCTION}

Business Intelligence (BI) has been established as an integral element of the solution for providing businesses with crucial information in the decision-making process, ensuring sustainability, and creating shareholder value. It has been increasingly used in diverse industries, including manufacturing, telecommunications, finance and securities, banking, insurance, and retail [1].

The analysis of business information by BI supports and enhances the decision-making process of the management related to a wide range of activities. For instance, small and medium-sized enterprises (SMEs) have employed BI to improve their returns on investment (ROI) and enhance customer loyalty. Nevertheless, an estimated failure rate of BI projects is still high, around 50\% [2]. Although both significance of and interest in BI systems are on the rise, not sufficient studies have been conducted on the critical success factors (CSFs) behind the implementation of those systems. Yet, evidently, the systems fail without the CSFs [3].

Accordingly, Kanaracus [4] argued that more studies on the CSFs in relation to BI should be carried on. following the assertion of Chang, Cheung, Cheng and Yeung [5] that CSFs are critical for organizational success. The system implementation is likely to result in failure without proper identification of CSFs [6]. Thus, the crucial question is which factors are the most critical to BI system success. The aim of this study is to identify the most significant CSFs for small and medium-sized enterprises in Jordan. This study adopted the approach of previous studies, whereas the proposed conceptual framework aims to identify the most essential CSFs impacting the BI system implementation. Nevertheless, the best BI practices have not been the primary research focus [7].

\section{BUSINESS INTELLIGENCE}

There are numerous BI definitions. Primarily, contemporary BI focuses on decision making [8]. According to Davenport, previously, the focus was on the impact on Decision Support Systems (DSS) on automating core business processes and the way organizations aim to enhance decision making by using information. However, "traditional understandings of management responsibility" still represents the main obstacle for more contributing to these systems and tools.

The term Business Intelligence denotes computer-based techniques employed to identify, extract, and analyze business data (e.g., sales revenues, incomes, or costs by departments or products). BI technologies offer historical, current and future perspectives of business operations. Some typical functions of BI technologies predictive analytics, data mining, analytics, text mining, complex event processing, process mining, online analytical processing, benchmarking, business performance management, and reporting [9].

A data warehouse is one of the main components of the business intelligence system. They are highly effective in improving the operations of BI system and contribute to intelligent decision making. The data warehouse refers to "a subject-oriented, integrated, non-volatile, and time-variant collection of data in support of management's decisions." It enables on-line analytical processing (OLAP) through its collection of integrated data. 


\section{CRITICAL SUCCESS FACTORS FOR BUSINESS INTELLIGENCE}

Organizations typically perceive business intelligence as a technology solution. However, numerous external and internal aspects impact the outcome of business intelligence investments. Some of the factors are the skills of the technical resources, the support level from senior managers, the types of industries in which the organizations operate, the investment funding, and the quality of the data sources. Moreover, as in the case of other information systems, there can be a variety of obstacles to successful execution and implementation of BI [10]. Although BI is essential for businesses, not enough studies have been conducted on the assessment of BI practices in general and CSFs in specific $[3,11]$.

Which factors have the most significant impact on the BI solution depends on the organizational type and the SMEs. However, it is challenging for organizations is to identify which are exactly those factors. One criterion organization should take into account is that the factors should have an impact during the duration of the project. This impact can be partial, through the guidelines on meeting the target for a given factor. On the other hand, full control refers to the precise expectations of the target for the factor [10, 12]. An organization should focus on these factors and accordingly, offer the platform for improving the success of the information technology solutions [13, 14].

Several empirical studies on CSFs in BI have been carried out in recent years $[3,15]$. These studies singled out user involvement, software source, data quality, and committed top management support as essential CSFs. Nevertheless, organizations are not always aware of the advantages of BI [2]. This assumption was confirmed by Hawking and Sellitto [15]. As Hawkins (2010) warns, organizations frequently do not understand that a higher quality of decisions is the primary driver of using BI. As business intelligence systems are complex entities, they are expensive as well [3]. Hence, it is necessary to efficiently manage, evaluate and justify costs and ensure that information encounters defined requirements [16].

As CSFs evolve gradually, it is assumed that different scholars propose various CSFs [17]. It can be concluded from this literature review on CSFs that support of top management is crucial for all phases of the successful implementation process of BI systems $[6,18]$. Change management is particularly important Table 1. Survey on critical success factors of BI

\begin{tabular}{|c|c|c|}
\hline Author /year & \multicolumn{2}{|c|}{ Critical Success Factors } \\
\hline $\begin{array}{l}\text { Olszak and } \\
\text { Ziemba [20] }\end{array}$ & $\begin{array}{l}\text { Good communication/feedback. } \\
\text { Clear business problem and processes. } \\
\text { Adequate budget. } \\
\text { Well defined business vision and plan. } \\
\text { Project management. } \\
\text { Qualified managers, team, and staff. } \\
\text { Management Support. } \\
\text { Good cooperation and experience with a BI } \\
\text { provider. } \\
\text { Culture. } \\
\text { Change management } \\
\text { Data quality. }\end{array}$ & $\begin{array}{l}\text { Leadership (Competent BI project } \\
\text { manager). } \\
\text { Clear users' expectation } \\
\text { (information requirements). } \\
\text { Integration between other systems } \\
\text { (i.e. ERP) and BI system. } \\
\text { BI flexibility and responsiveness on } \\
\text { users' requirements. } \\
\text { Fitting the BI solution to the } \\
\text { business requirements (users' } \\
\text { expectation). } \\
\text { Appropriate technology and tools. } \\
\text { "User friendly" (usability) BI } \\
\text { system. }\end{array}$ \\
\hline $\begin{array}{l}\text { Wixom and } \\
\text { Watson [22] }\end{array}$ & $\begin{array}{l}\text { Skilled project team. } \\
\text { User participation. } \\
\text { Data quality. }\end{array}$ & $\begin{array}{l}\text { Adequate resources. } \\
\text { Management support. } \\
\text { System quality. }\end{array}$ \\
\hline $\begin{array}{l}\text { Adamala and } \\
\text { Cidrin [23] }\end{array}$ & $\begin{array}{l}\text { Process dimension } \\
\text { Balanced team composition and } \\
\text { Business-centric championship. } \\
\text { Technological dimension. } \\
\text { Organizational dimension } \\
\text { Clear vision. } \\
\text { Well defined business case. } \\
\text { Management Support }\end{array}$ & $\begin{array}{l}\text { Scalable, business-driven, } \\
\text { Sustainable integrity and data } \\
\text { quality. } \\
\text { Change management. } \\
\text { Iterative and business-driven } \\
\text { development methodology. } \\
\text { Flexible technical } \\
\text { Framework. }\end{array}$ \\
\hline $\begin{array}{l}\text { Xu and Hwang } \\
{[21]}\end{array}$ & $\begin{array}{l}\text { User involvement/participation. } \\
\text { Top management support. }\end{array}$ & $\begin{array}{l}\text { Clearly defined business } \\
\text { needs/benefits. }\end{array}$ \\
\hline $\begin{array}{l}\text { Yeoh and } \\
\text { Koronios [3] }\end{array}$ & $\begin{array}{l}\text { Change management. } \\
\text { Team. } \\
\text { Project management and methodology } \\
\text { Effective communications. } \\
\text { Committed management support and sponsorship. }\end{array}$ & $\begin{array}{l}\text { Infrastructure. } \\
\text { Championship and management. } \\
\text { Integrity and data quality. } \\
\text { Vision and business case. }\end{array}$ \\
\hline
\end{tabular}




\begin{tabular}{|c|c|c|}
\hline Author /year & \multicolumn{2}{|c|}{ Critical Success Factors } \\
\hline Vodapalli [24] & $\begin{array}{l}\text { Change management. } \\
\text { Project management and business driven } \\
\text { methodology. } \\
\text { Sponsorship and Committed management support. } \\
\text { Team structure/building. } \\
\text { Planning and clear vision. }\end{array}$ & $\begin{array}{l}\text { Iterative prototyping usage to outline } \\
\text { scope and requirements. } \\
\text { Performance considerations. } \\
\text { Solutions mapping to the users. } \\
\text { User support and training. } \\
\text { Management issues and data quality. }\end{array}$ \\
\hline $\begin{array}{l}\text { Muscatello and } \\
\text { Chen [25] }\end{array}$ & $\begin{array}{l}\text { Business-driven methodology and project } \\
\text { management. } \\
\text { Committed management support and sponsorship. } \\
\text { Business-centric championship. } \\
\text { Clear business vision and well-established case. } \\
\text { Business user-oriented change management. }\end{array}$ & $\begin{array}{l}\text { Business-centric championship. } \\
\text { Team structure/building. } \\
\text { Technical framework for strategic } \\
\text { and extensible planning. } \\
\text { Governance framework and } \\
\text { sustainable data quality. }\end{array}$ \\
\hline $\begin{array}{l}\text { Sammon and } \\
\text { Finnegan [26] }\end{array}$ & $\begin{array}{l}\text { Management support. } \\
\text { Flexible enterprise model. } \\
\text { Sufficient resources. } \\
\text { Data stewardship. } \\
\text { Business driven approach. } \\
\text { Data quality. }\end{array}$ & $\begin{array}{l}\text { Solution proof of concept. } \\
\text { Strategy for automated data. } \\
\text { Extraction tools/methods. } \\
\text { Integration of existing systems with } \\
\text { data warehouse. }\end{array}$ \\
\hline $\begin{array}{l}\text { Poon and } \\
\text { Wagner [27] }\end{array}$ & $\begin{array}{l}\text { Operating sponsor. } \\
\text { Business objectives. } \\
\text { Executive sponsor. } \\
\text { Technology and IT staff, } \\
\text { Management of data. }\end{array}$ & $\begin{array}{l}\text { Organizational resistance. } \\
\text { Defined requirements. } \\
\text { System evolution. } \\
\text { Methodology of development. }\end{array}$ \\
\hline $\begin{array}{l}\text { Mukherjee and } \\
\text { D'Souza [28] }\end{array}$ & $\begin{array}{l}\text { Technology fit. } \\
\text { Clear business objectives. } \\
\text { Data quality. }\end{array}$ & $\begin{array}{l}\text { Management support. } \\
\text { Change management. } \\
\text { User involvement. }\end{array}$ \\
\hline
\end{tabular}

CSF. Accordingly, it can be argued that Consequently, organizational critical success factors are more essential than the technical ones [2,6]. Hence, the argument by Markus and Tanis [19] that an ERP system implementation does not simply represent an IT project is confirmed.

As argued by Olszak and Ziemba [20], the BI implementation CSFs are adequate budget, leadership, business problem and processes, usability, technology, flexibility, system integration, business expectation, users' expectation, culture, experience and cooperation, data quality, skill, effective change management, good communication, project management, top management support, and clear business vision and plan. Likewise, Xu and Hwang [21] singled out user involvement, clearly defined business model, and top management support as the main factors behind the successful BI implementation. In the Delphi study, Yeoh and Koronios [3] investigated the impact of a set of CSFs on BI. As shown in Table 1, the study concluded that the main CSFs are the infrastructure related, management and championship, data quality and integrity, team, change management, effective communications, project management and methodology, and committed management support and sponsorship.

However, those studies were performed on firms in the developed countries. Hence, the findings cannot be automatically applied to firms in the developing countries. According to Moohebat and Asemi [29], CSFs relevant for BI in various countries might be different. Thus, Upadhyay, Basu, Adhikary and Dan [30] conducted a study on the impact of CSFs on SMEs in India. The issues leading to the successful BI implementation are contextdependent [31,32].The model of BI implementation presented in Figure 3.2 is based on relevant works on the industry, and it shows which most influential factors were identified: 


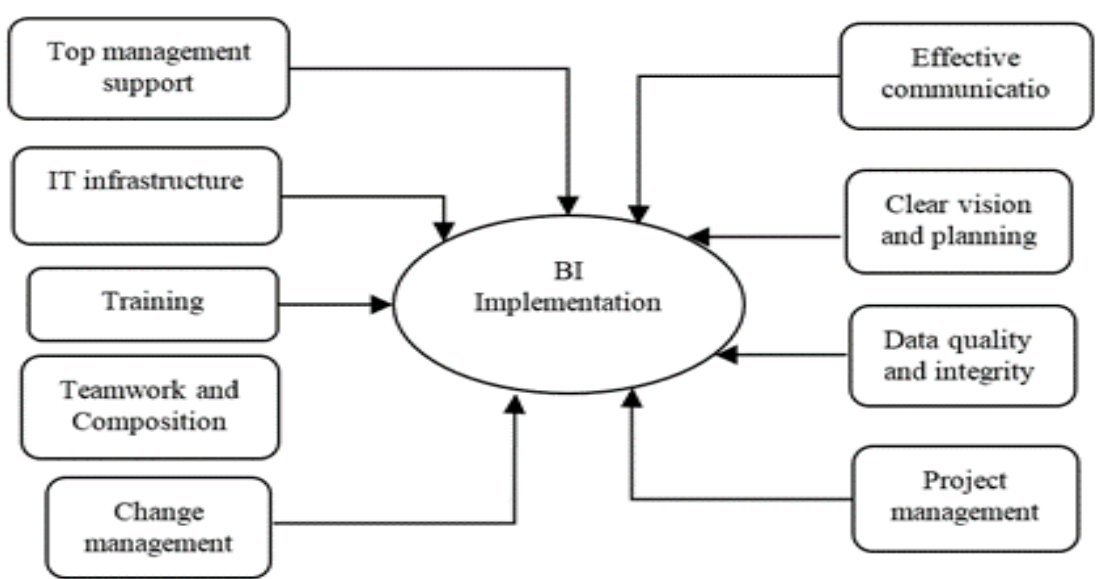

Figure 1: The conceptual framework of CSFs for BI Implementation Success.

This study reviewed relevant studies in order to explore the most important CSFs for the successful BI implementation. Subsequently, the applicability of the explored critical success factors to SMEs was assessed. The purpose is to use findings on the critical success factors to propose tools for monitoring and improving the BI implementation in SMEs. Nevertheless, it is crucial to obtain the managerial support to BI systems in addition to the implementation and deployment stage [20]. Moreover, it is a responsibility of the management to make sure that BI systems are in line with the strategic business goals. Besides, in order to implement BI systems successfully, end-user training should be encouraged and [29-33]. According to Remus [34] and Hasibuan and Dantes [35], According to the International Data Corporation (IDC) the businesses that exceptionally employ BI could achieve over a three-year period an regular of $401 \%$ return on investment [10]. Therefore, the objectives of BI systems can be realized at the earliest stages of the project, whereas the in-house training is essential for facilitating the progress of BI implementation [36].

This study proposed a CSFs framework for BI Implementation Success. The process perspective is associated with training, change management, balanced team composition, and effective project management. What is more, the organizational perspective focuses on business processes and organizational structure [37]. Furthermore, the technological perspective deals with particular technical aspects of BU products such as base software and hardware needs (i.e., IT infrastructure and data and information quality). Lastly, the performance perspective measures the BI use and implementation as it is concerned with the BI output and its influence on the organization.

\section{CONCLUSION}

Business Intelligence (BI) represents a business management tool. It consists of technologies and applications employed to collect and analyze business-related information, SMEs use Business Intelligence systems to investigate the factors impacting the enterprises business in order to assist them in the decision-making processes. $\mathrm{BI}$, as a distinct discipline, can be studies from a process and a system perspective. However, so far, not sufficient studies have identified and examined proper CSFs for the successful BI implementation. Thus, this research brings valuable insight into main factors behind the implementation of BI systems. In addition to critical factors, the consolidated CSFs framework takes into consideration the contextual elements as well and accordingly, provides an in-depth understanding of CSFs. In particular, it emphasizes a need for improved communication of the value of BI. The support/commitment of top management is essential for overcoming obstacles to the BI adoption such as lack of skilled resources, labor, money, and time, and issues related to human capital. Moreover, organizations draw upon their current experience with external data sources and enterprise technologies. In addition, a skilled project team, availability of resources, and end-user involvement are essential for implementing a successful business intelligence project. As confirmed by this one and previous studies, more experience contributes to success significantly.

\section{References}

1 Olszak, C.M., and Ziemba, E.: 'Approach to building and implementing business intelligence systems', Interdisciplinary Journal of Information, Knowledge, and Management, 2007, 2, pp. 134-148

2 Nofal, M.I.M., and Yusof, Z.M.: 'Conceptual model of enterprise resource planning and business intelligence systems usage', International Journal of Business Information Systems, 2016, 21, (2), pp. 178-194

3 Yeoh, W., and Koronios, A.: 'Critical success factors for business intelligence systems', Journal of computer information systems, 2010, 50, (3), pp. 23-32

4 Kanaracus, C.: 'Biggest ERP Software Failures of 2011', Network World, 2011

5 Chang, M.K., Cheung, W., Cheng, C.H., and Yeung, J.H.Y.: 'Understanding ERP system adoption from the 
user's perspective', International Journal of Production Economics, 2008, 113, (2), pp. 928-942

6 Schniederjans, D., and Yadav, S.: 'Successful ERP implementation: an integrative model', Business Process Management Journal, 2013, 19, (2), pp. 364-398

7 Hwang, M.I.: 'Success factors for business intelligence: perceptions of business professionals', in Editor $(\text { Ed. })^{\wedge}($ Eds.): 'Book Success factors for business intelligence: perceptions of business professionals' (2009, edn.), pp. 484-490

8 Davenport, T.H.: 'Business intelligence and organizational decisions', Organizational Applications of Business Intelligence Management: Emerging Trends: Emerging Trends, 2012, pp. 1

9 Nofal, M.I., and Yusof, Z.M.: 'Integration of Business Intelligence and Enterprise Resource Planning within Organizations', Procedia Technology, 2013, 11, (0), pp. 658-665

10 Olbrich, S., Poeppelbuss, J., and Niehaves, B.: 'BI Systems Managers' Perception of Critical Contextual Success Factors: A Delphi Study', 2011

11 Arnott, D.: 'Success factors for data warehouse and business intelligence systems', ACIS 2008 Proceedings, 2008, pp. 16

12 Nofal, M.I., and Yusof, Z.M.: 'Critical success factors enhancing enterprise resource planning systems implementation in Jordanian SMEs', in Editor (Ed.)^(Eds.): 'Book Critical success factors enhancing enterprise resource planning systems implementation in Jordanian SMEs’ (IEEE, 2015, edn.), pp. 98-103

13 Mukred, M., and Yusof, Z.M.: 'The Role of Electronic Records Management (ERM) for supporting Decision making Process in Yemeni Higher Professional Education (HPE): A Preliminary Review', Jurnal Teknologi, 2015, 73, (2)

14 Alali, H., and Salim, J.: 'Information system success and acceptance theories: Towards developing a "virtual communities of practice" success model', in Editor (Ed.)^(Eds.): 'Book Information system success and acceptance theories: Towards developing a "virtual communities of practice" success model' (IEEE, 2011, edn.), pp. 306-312

15 Hawking, P., and Sellitto, C.: 'Critical Success Factors of Business Intelligence (BI) in an ERP Systems Environment', 2010

16 Lönnqvist, A., and Pirttimäki, V.: 'The measurement of business intelligence', Information Systems Management, 2006, 23, (1), pp. 32

17 Rockart, J.F.: 'Chief executives define their own data needs', Harvard business review, 1978, 57, (2), pp. 8193

18 Méxas, M.P., Quelhas, O.L.G., and Costa, H.G.: 'Prioritization of enterprise resource planning systems criteria: Focusing on construction industry', International Journal of Production Economics, 2012, 139, (1), pp. 340-350

19 Markus, M.L., and Tanis, C.: 'The enterprise systems experience-from adoption to success', Framing the domains of IT research: Glimpsing the future through the past, 2000, 173, pp. 207-173

20 Olszak, C.M., and Ziemba, E.: 'Critical Success Factors for Implementing Business Intelligence Systems in Small and Medium Enterprises on the Example of Upper Silesia, Poland', Interdisciplinary Journal of Information, Knowledge, and Management, 2012, 7

$21 \mathrm{Xu}, \mathrm{H}$., and Hwang, M.I.: 'The effect of implementation factors on data warehousing success: An exploratory study', 2007

22 Wixom, B.H., and Watson, H.J.: 'An empirical investigation of the factors affecting data warehousing success', MIS quarterly, 2001, pp. 17-41

23 Adamala, S., and Cidrin, L.: 'Key Success Factors in Business Intelligence', Journal of Intelligence Studies in Business, 2011, 1, (1)

24 Vodapalli, T.: 'Critical Success Factors of BI Implementation', IT University of Copenhagen. http://mit. itu. dk/ucs/pb/download/BI\% 20T hesis\% 20Report-New. pdf, 2009

25 Muscatello, J.R., and Chen, I.J.: 'Enterprise resource planning (ERP) implementations: theory and practice', International Journal of Enterprise Information Systems (IJEIS), 2008, 4, (1), pp. 63-83

26 Sammon, D., and Finnegan, P.: 'The ten commandments of data warehousing', ACM SIGMIS Database, 2000, 31, (4), pp. 82-91

27 Poon, P., and Wagner, C.: 'Critical success factors revisited: success and failure cases of information systems for senior executives', Decision Support Systems, 2001, 30, (4), pp. 393-418

28 Mukherjee, D., and D'Souza, D.: 'Think phased implementation for successful data warehousing', Information Systems Management, 2003, 20, (2), pp. 82-90

29 Annamalai, C., and Ramayah, T.: 'Enterprise resource planning (ERP) benefits survey of Indian manufacturing firms: An empirical analysis of SAP versus Oracle package', Business Process Management Journal, 2011, 17, (3), pp. 495-509

30 Moohebat, M., and Asemi, A.: 'A comparative study of critical success factors (CSFs) in implementation of ERP in developed and developing countries', 2010 
31 Dezdar, S., and Ainin, S.: 'The influence of organizational factors on successful ERP implementation', Management Decision, 2011, 49, (6), pp. 911-926

32 Ganesh, L., and Mehta, A.: 'Critical success factors for successful enterprise resource planning implementation at Indian SMEs', International Journal of Business, Management and Social Sciences, 2010, 1, (1), pp. 65-78

33 Aman, A., Al-Shbail, T.A., and Mohammed, Z.: 'Enhancing Public Organizations Accountability through EGovernment Systems', International Journal of Conceptions on Management and Social Science, 2013, 1, (1), pp. $15-21$

34 Remus, U.: 'Critical success factors for implementing enterprise portals: A comparison with ERP implementations’, Business Process Management Journal, 2007, 13, (4), pp. 538-552

35 Hasibuan, Z.A., and Dantes, G.R.: 'Priority of Key Success Factors (KSFS) on Enterprise Resource Planning (ERP) System Implementation Life Cycle', Journal of Enterprise Resource Planning Studies, 2012, 2012, pp. $1-15$

36 Ziemba, E.: 'Conceptual model of information technology support for prosumption', in Editor (Ed.)^(Eds.): 'Book Conceptual model of information technology support for prosumption' (2013, edn.), pp. 355-363

37 Annamalai, C., and Ramayah, T.: 'Does the organizational culture act as a moderator in Indian enterprise resource planning (ERP) projects?: An empirical study', Journal of Manufacturing Technology Management, 2013, 24, (4), pp. $555-587$ 